\title{
PENGARUH CORPORATE RISK, LEVERAGE DAN SALES GROWTH TERHADAP TAX AVOIDANCE PADA PERUSAHAAN SEKTOR PERTAMBANGAN
}

\author{
Namira Ufrida Rahmi *, Desika Nur'saadah , Freddy Salim \\ Fakutas Ekonomi, Universitas Prima Indonesia \\ Namiraufridarahmi@unprimdn.ac.id, Desikasim1997@gmail.com, Freddysalim21@gmail.com
}

\begin{abstract}
The purpose of this study is to find out and analyze the effect of corporate risk, leverage, sales growth on tax avoidance. Tax avoidance measurement using cast effective tax rate of the mining companies listed on the indonesian stock exchange from 2015-2017. Samples in this study used nonprobability sampling method with purposive sampling technique with 81 samples. Data in this study were analyzed with multiple and simple linear analysis techniques. The result of this study indicates that sales growth has a positive effect on tax avoidance, while the negative effect of corporate risk and leverage on tax avoidance.
\end{abstract}

Keywords :Corporate Risk, Leverage, Sales Growth, Tax Avoidance

\section{PENDAHULUAN}

Pada dasarnya pajak ialah sumber utama penerima ataupun pendapatan suatu negara untuk kesejahteraan Indonesia. Dalam mencapai kesejahteraan Indonesia pemerintah mengunakan pajak untuk melaksanakan pembangunan nasional. Semakin besar kesadaran masyarakat untuk membayar pajak maka semakin besar perkembangan Indonesia dan pemerintah lebih mudah untuk menyediakan fasilitas untuk masyarakat. Akan tetapi bagi wajib pajak, pajak suatu beban yang secara langsung mengurangi laba/penghasilan yang diperoleh oleh mereka. Dan pemerintah ingin menerima pajak yang terus menerus meningkat. Penghindaran pajak memiliki persoalan yang cukup rumit dikarenakan di sisi lain penghindaran pajak dapat dilakukan, akan tetapi penghindaran pajak tidak juga diingankan karena memakin wajib pajak menghindari maka akan semakin susah untuk kedepannya

Sales Growth(tingkat pertumbuhan), pada perusahaan tidak bisa menetapkan seberapa besar pendapatan/laba yang dihasilkan dikarena pendapatan masyarakat tidak bisa diketahui. Banyaknya saingan diluar sana, dengan barang yang sama tetapi dengan harga yang lebih murah dan masyarakat selalu ingin persediaan/kebutuhan yang diperlukan tetapi dengan harga yang terjangkau. Corporate Risk(resiko perusahaan) inilah salah satu ancaman bagi suatu perusahaan agar dapat membayar pajak dapat ditingkatkan dari tahun ke tahun. Dalam mengukur penghindaran pajak dilakukan dengan beberapa cara yang salah satunya ialah membandingkan kas yang dikeluarkan untuk membayar pajak dengan laba sebelum pajak atau Cash Effective Task Rate(CETR). Dengan mengunakan metode ini dapat dilihat bagaimana usaha perusahaan menekan kewajiban pajaknya secara rill. Dengan metode Cash Effective Task Rate(CETR), apabila peresentase CETR-nya semakin tinggi maka tingkat penghindaran pajak perusahaan semakin rendah. Perusahaan akan lebih memilih mengurangi pajak yang wajib dibayarkan melalui penghindaran pajak karena dalam melaksakan praktik pengurangan pajak yang dilakukan oleh perusahaan, tetap memenuhi ketentuan dan peraturan pajak yang berlaku yakni dengan memanfaatkan 
pengecualian dan potongan pajak yang dapat dilakukan secara legal ataupun dengan cara menunda pajak yang sebelumnya tidak diakaui dalam peraturan pajak yang berlaku (Dewinta dan setiawan 2016).

Distorsi dalam sistem perpajakan juga merupakan salah satu faktor penyebab terjadinya penghindaran pajak. Wajib pajak berpendapat bahwa unsur pokok dalam sistem perpajakan kurang optimal. Salah satunya kurang selarasnya kebijakan perpajakan antara pusat dan daerah yang mengakibatkan keuntungan rasa kepercayaan wajib pajak. Peraturan pajak yang multi interpretative dan tindakan korupsi juga dapat mengakibatkan iklim perpajakan menjadi kondusif untuk melakukan upaya Tax Avoidance.

\section{KAJIAN LITERATUR}

\section{Pajak dan Penghindaran Pajak ( Tax Avoidance )}

Menurut Undang-Undang No 28 Tahun 2007 pasal 1 ayat 1, pajak dapat diartikan sebagai suatu kontribusi bagi wajib pajak pribadi atau badan kepada negara yang bersifat wajib dan memaksa berdasarkan undang-undang dengan tidak menimbulkan imbalan secara langsung dan digunakan untuk keperluan negara sebesar besarnya bagi kemakmuran rakyat. Pajak bersifat wajib bagi wajib pajak perorangan maupun badan (perusahaan) yang harus disetorkan kepada negara. Namun, para wajib pajak cenderung enggan mengorbankan pendapatan yang diperoleh dari hasil operasi perusahaan disetorkan pada negara. Para pemilik perusahaan juga tidak dapat sepenuhnya menghindar dari kewajiban mereka terkait pemenuhan dalam pembayaran pajak tetapi hanya dapat mengurangi jumlah pajak yang disetorkan kepada pemerintah tanpa ada implikasi terjadinya restitusi pajak atau kurang bayar pajak.

Menurut Santoso dan Rahayu (2013), terdapat tiga cara bagi wajib pajak dalm menghindari kewajiban pemenuhan pajak mereka, yaitu:

a) menahan diri, maksudnya disini adalah wajib pajak disarankan untuk menghindari suatu kegiatan yang apabila dilakukan bisa dikenai pajak seperti tidak merokok agar dapat terhindar dari cukai tembakau;b) pindah lokasi, maksudnya disini dengan berpindah atau lokasi usaha kedasar yag dasar pengenakan pajaknya lebih rendah seperti keringanan pajak bagi para investor yang hendak menanamkan modal usaha mereka ke wilayah Indonesia bagian timur;c) penghindaran pajak secara yuridis. Perbuatan ini dilakukan dengan cara sedemikian rupa sehingga perbuatan-perbuatan yang dilakukan tidak terkena pajak. Biasanya dilakukan dengan memanfaatkan kekosongan atau ketidakjelasan undang-undang (loopholes).

\section{BTG = EBT - Laba kena pajak}

\section{Corporate Risk}

Corporate Risk mencerminkan penyimpangan atau deviasi standart dari earning baik penyimpangan itu bersifat kurang dari yang direncanakan atau mungkin lebih dari yang direncanakan, semakin besar deviasi earning perusahaan mengindikasikan semakin besar pula risiko perusahaan yang ada.Oleh Paligrova (2010) dalam Budi dan Setiyono (2012) untuk mengukur resiko perusahaan ini dihitung melalui deviasi standar dari EBITDA (Earning Before Income Tax, Depreciation, and Amortization) dibagi dengan total asset perusahaan. Rumus deviasi standar tersebut adalah sebagai berikut : 


$$
\mathrm{RISK}=\sqrt{\sum_{T-1}^{T}\left[E-\frac{1}{T} \sum_{T-1}^{T} E\right]^{2}}
$$

Atau EBITDA

Total asset

\section{Leverage}

Leverage merupakan tingkat hutang yang digunakan perusahaan dalam melakukan pembiayaan atau pembelian asset asset perusahaan. Leverage menggambarkan tingkat resiko dari perusahan yang diukur dengan membandingkan total kewajiban perusahaan dengan total aktiva yang dimiliki peusahaan (Surbakti, 2012).

Debt to Total Asset Ratio atau biasanya disebut DAR merupakan salah satu bagian dari leverage, DAR merupakan suatu perbandingan yang digunakan dalam mengukur seberapa besar jumlah aset perusahaan yang dibiayai dengan memanfaatkan sejumlah utang dari pihak ketigaatau kreditur. Adanya utang dari pihak ketiga dapat mengakibatkan bertambahnya beban bunga yang wajib dibayar oleh perusahaan kepada kreditur. Beban bunga yang dapat mengakibatkan kekurangan laba yang diperoleh perusahaan sehingga beban pajak yang wajib dibayarkan oleh perusahaan juga berkurang.

Dalam perhitungan DAR dapat mengunakan rumus :

\section{DAR = Total Utang}

\section{Total Aset}

\section{Sales Growth}

Sales growth (pertumbuhan penjualan) merupakan tingkat pertumbun penjualan suatu perusahaan dari tahun ke tahun sehingga dapat mencerminkan prospek dan profitabilitas suatu perusahaan pada masa yang akan datang. Tingkat pertumbuhan penjualan suatu perusahaan secara umumnya diukur dengan membandingkan penjualan tahun berjalan dikurangi dengan penjualan perusahaan pada tahun sebelumnya. Apabila tingkat pertumbuhan penjualan suatu perusahaan meningkat maka profitabilitas pun akan meningkat dan kinerja perusahaan juga dapat diartikan semakin baik, karena dengan meningkatnya profitabilitas perusahaan, maka laba yang diperoleh perusahaan dari tahun ke tahun.

Dalam mengukur tingkat pertumbuhan penjualan dapat digunakan rumus sebagai berikut :

\section{SG = Penjualantahunsekarang - Penjualantahunsebelumnya}

\section{Penjualantahunsebelumnya}

Dengan membandingkan penjualan dari tahun tahun sebelumnya, perusahaan dapat memanfaatkan sumber daya yang dimiliki secara lebih optimal. Dengan mengukur tingkat pertumbuhan penjualan perusahaan dari tahun ke tahundapat diketahui apakah kinerja suatu perusahaan semakin baik atau semakin buruk. Suatu perusahaan juga dapat memprediksi kearah mana perusahaan akan berjalan kedepannya sehingga hasil yang diperoleh lebih bagus dari tahun ke tahun. Dewinta dan Setiawan (2016) mengatakan bahwa peningkatan pertumbuhan penjualan cenderung akan membuat perusahaan mendapatkan laba yang besar, maka dari itu perusahaan akan cenderung untuk melakukan praktik tax avoidance.

\section{Pengaruh Corporate Risk Terhadap Penghindaran Pajak}

Dalam perusahaan terdapat dua karakteristik yang dimiliki oleh pemimpin perusahaan yaitu risk taker dan risk averse. Pimpinan perusahaan yang memiliki karakter risk taker cenderung lebih berani 
dalam mengambil keputusan yang memiliki tingkat berisiko yang tinggi namum memilik tingkat return yang tinggi pula(Low, 2006 ). Sedangkan pemimpin yang bersifat risk averse, memiliki karakteristik lebih cenderung kurang berani dalam pengambilan keputusan yang beresiko tinggi sehingga labayang hasil diperoleh tidak sebanding dengan laba yang hasil pemimpin yang cencerung bersifat risk taker. Pemimpin yang bersifat risk taker biasanya pemimpin yang memiliki usia yang lebih tua dan memiliki ketergantungan terhadap perusahaan sehingga cenderung lebih memilih main aman. Dengan memperhatikan besar kecilnya resiko bisnis yang diambil perusahaan, maka dapat diketahui apakah pemimpin perusahaan tersebut merupakan pemimpin yang memiliki karakterisktik seorang risk taker atau seorang pemimpin yang memiliki karakteristik risk averse. Resiko perusahaan merupakan cerminan dari policy yang berani diambil oleh seorang pemimpin perusahaan(Budiman 2012). Menurut Paglivora 2010, resiko perusahaan merupakan volatilitas earning perusahaan, yang dapat diukur dengan rumus deviasi standar. Dapat di artikan resiko perusahaan merupakan suatu penyimpangan standart dari earning baik penyimpangan bersifat kurang dari yang direncanakan. Semakin besar deviasi earning dalam perusahaan semakin besar resiko perusahaan.

\section{Pengaruh Leverage Terhadap Penghindaran Pajak}

Leverage merupakan seberapa efektif perusahaan dalam mengunakan hutang hutang yang dimiliki perusahaan terhadap pembiayaan ataupun pembelian asset. Leverage menggambarkan tingkat resiko dari perusahan yang diukur dengan membandingkan total kewajiban perusahaan dengan total aktiva yang dimiliki perusahaan (Surbakti, 2012). Leverage merupakan rasio yang menunjukan besarnya utang yang dimiliki oleh perusahaan untuk membiayai aktifitas operasinya(Darmawan dan Sukartha 2014). Berdasarkan peraturan perpajakan pasal 6 ayat 1 UU no 36 tahun yang mengatur tentang PPh, bunga pinjaman merupakan biaya yang dapat dikurangi dengan penghasilan kena pajak. Dengan demikian, beban bunga yang mengurangi laba perusahaan juga mengakibatkan pajak yang harus dibayar oleh perusahaan juga berkurang. Hal ini berbeda apabila pembiayaan perusahaan mengunakan equity financing dalam pembiayaan asset dan kegiatan usaha, maka perusahaan harus membayar deviden kepada investor yang mana tidak dapat mengurangi penghasilan kena pajak (Surbakti, 2012).

\section{Pengaruh Sales Growth Terhadap Penghindaran Pajak}

Sales growth (pertumbuhan penjualan) juga dapat berpengaruh terhadap pratik penghindaran pajak. Hal ini dapat dibuktikan dalam penelitian yang dilakukan oleh Budiman dan Setiyono (2012) yang menjelaskan bahwa sales growth berpengaruh signifikan terhadapat Cash Effective Tax Ratio (CETR) yang mana merupakan indikator dari adanya aktivitas tax avoidance pada perusahaan manufaktur yang terdaftar di BEI tahun 2006-2010. Pertumbuhan penjualan mencerminkan manifestasi keberhasilan investasi periode masa lalu dan dapat dijadikan sebagai prediksi pertumbuhan masa yang akan datang. Dengan menggunakan pengukuran pertumbuhan penjualan perusahaan dapat memprediksi seberapa besar profit yang akan diperoleh dengan besarnya pertumbuhan penjualan( Deitiani 2011 ). Semakin besar volume penjualan menunjukan penjualan suatu perusahaan semakin meningkat. Pendapatan didukung dari hasil penelitian yang dilakukan oleh Dewinta dan Setiawan (2016), dimana penelitian tersebut menunjukan hasil bahwa sales growth berpengaruh positif terhadap penghindaran pajak.

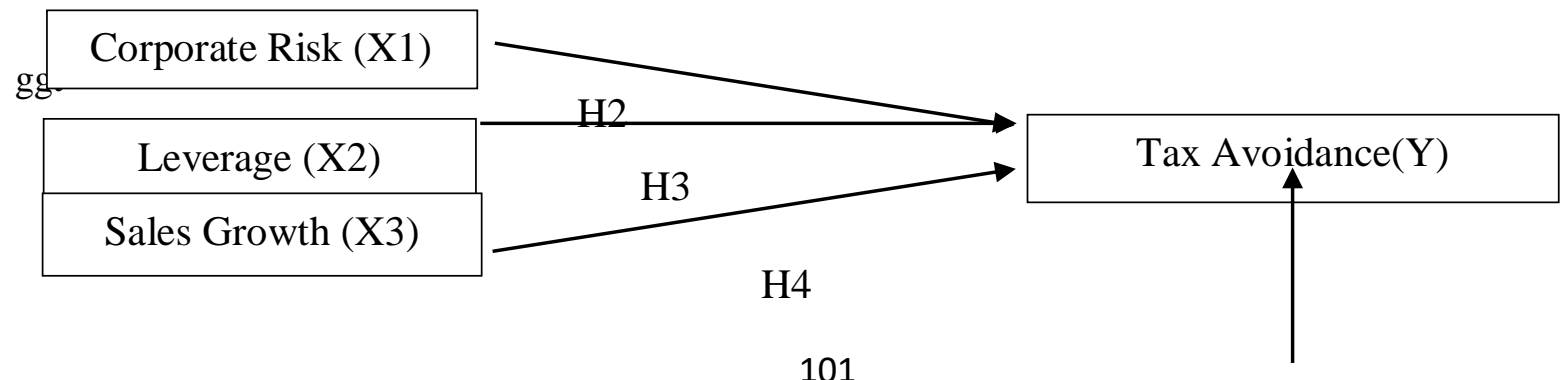




\section{Gambar 1. Kerangka Konseptual}

1. H1 : Corporate Risk berpengaruh terhadap Tax Avoidance pada sektor pertambangan yang terdaftar di BEI 2015-2017

2. H2 : Leverage berpengaruh terhadap Tax Avoidance pada sektor pertambangan yang terdaftar di BEI 2015-2017

3. H3 : Sales Growth berpengaruh terhadap Tax Avoidance pada sektor pertambangan yang terdaftar di BEI 2015-2017

4. H4 :Corporate Risk, Leverage dan Sales Growth berpengaruh terhadap Tax Avoidance pada sektor pertambangan yang terdaftar di BEI 2015-2017.

\section{METODOLOGI PENELITIAN}

Pendekatan penelitian yang digunakan peneliti adalah dengan metode kuantitatif. Metode kuantitatif ini menggunakan data yang bersifat linear artinya proses penelitian ini memiliki langkah langkah yang sistematis. Data yang digunakan dapat berupa angka. Hal ini sesuai dengan pernyataan Sugiyono (2016 : 7). Jenis penelitian deskriptif yang digunakan oleh peneliti . Menurut Sugiyono (2016 : 53) penelitian deskriptif adalah rumusan masalah yang berkenaan dengan pertanyaan terhadap keberadaan satu variabel atau lebih. Sifat penelitian yang digunakan peneliti adalah penelitian kausal komparatif dan bisa disebut hubungan sebab akibat. Menurut Sugiyono (2016 : 37), hubungan kausal adalah hubungan yang bersifat sebab akibat.

\section{Objek/ Subjek Penelitian}

Objek yang digunakan dalam penelitian ini adalah kualitas audit, keaktifan komite audit, dan struktur kepemilikan institusional. Subjek yang digunakan dalam penelitian ini adalah perusahaan pertambangaan yang terdaftar di Bursa Efek Indonesia tahun 2015-2017.

\section{Populasi}

Peneliti ini dilakukan pada perusahaan pertambangan dengan populasi sebanyak 41 perusahaan pertambangan yang terdaftar di Bursa Efek Indonesia (BEI) periode 2015 - 2017.

\section{Sampel}

Tabel 1.

Kriteria Pemilihan Sampel

\begin{tabular}{|c|c|}
\hline Keterangan & Jumlah \\
\hline Perusahaan sektor pertambangan yang terdaftar di BEI & 41 \\
\hline $\begin{array}{l}\text { 1. Perusahaan sektor pertambangan yang tidak memiliki laporan } \\
\text { keuangan lengkap periode 2015-2017 } \\
\text { 2. Perusahaan sektor pertambangan yang hasil perhitungan nol } \\
\text { dan data tidak lengkap }\end{array}$ & $\begin{array}{l}(3) \\
(8)\end{array}$ \\
\hline Jumlah perusahaan yang menjadi sampel penelitian & 30 \\
\hline
\end{tabular}

Sumber : www.idx.co.id 
Jumlah data yang dijadikan sampel dalam penelitian ini adalah sebanyak 30 perusahaan. Data yang digunakan dalam penelitian ini adalah 3 tahun dikali dengan 30 perusahaan sebanyak 90 perusahaan. Dimana ada sebanyak 11 perusahaan yang tidak memenuhi kriteria dalam pemilihan sampel. Perusahaan sektor pertambangan yang tidak memiliki laporan keuangan lengkap periode 2015-2017 terdapat 3 perusahaan dan perusahaan sektor pertambangan yang memiliki data tidak lengkap 8 perusahaan. Teknik pengumpulan data inimengunakan teknik dokumentasi, yang artinya dilakukan dengan cara pengumpulan data yang berupa bukti fisik baik tulisan maupun gambar pada data sekunder ataupun laporan keuangan tahunan dari perusahaan pertambangan di Bursa Efek Indonesia periode 2015 - 2017. Data yang digunakan dalam penelitian ini menggunakan data sekunder yang didapatkan pada buku, artikel, dokumen, media dan lain-lain. Peneliti juga memperoleh data ini dari situs resmi Bursa Efek Indonesia www.idx.co.id.

\section{Teknik Analisis Data}

\section{Uji Normalitas}

Uji ini bertujuan untuk menguji apakah dalam model regresi, variabel pengganggu atau residual memiliki distribusi normal . Untuk menguji apakah residual berdistribusi normal atau tidak dapat dideteksi dengan analisis grafik atau uji statistik.

\section{Uji Multikolinearitas}

Uji ini bertujuan untuk menguji apakah model regresi ditemukan adanya korelasi antar variabel bebas. Untuk menguji multikolonieritas dapat ditunjukkan dengan menggunakan nilai Tolerance $\leq 0.10$ atau sama dengan nilai $\mathrm{VIF} \geq 10$.

\section{Uji Autokorelasi}

Uji ini bertujuan menguji apakah dalam model regresi linear ada korelasi antara kesalahan pengganggu pada periode t dengan kesalahan pengganggu pada periode t-1 (sebelumnya). Untuk menguji apakah ada autokorelasi dapat digunakan Uji Durbin-Watson (DW Test).

\section{Uji Heteroskedastistias}

Uji ini bertujuan untuk menguji apakah dalam model regresi terjadi ketidaksamaan variance dari residual satu pengamatan ke pengamtan yang lain. Untuk menguji ada atau tidaknya heteroskedastisitas dideteksi dengan Uji White.

\section{Uji Hipotesis secara Simultan ( Uji f)}

Uji hipotesis secara simultan digunakan untuk mengetahui apakah variabel independen secara bersama-sama atau simultan mempengaruhi variabel dependen.

\section{Uji Hipotesis secara Parsial ( Uji t)}

Uji t menunjukkan seberapa jauh pengaruh satu variabel penjelas/independen secara individual dalam menerangkan variansi variabel dependen.

\section{HASIL DAN PEMBAHASAN}

\section{Uji Normalitas}

Uji normalitas bertujuan untuk menguji apakah data residual sudah berdistribusi secara normal atau tidak normal. Penelitian ini menggunakan uji normalitas dengan statistik non-parametik Kolmogorov Smirnov Test merupakan pengambilan keputusan data distribusi normal dengan syarat sebagai berikut :

1. Jika nilai signifikan $>0,05$ maka distribusi normal.

2. Jika nilai signifikan $<0,05$ maka distribusi tidak normal. 


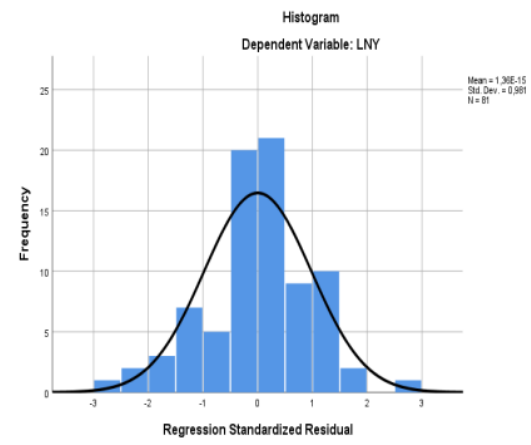

\section{Gambar 2. Histogram}

Berdasarkan grafik histogram diatas, dapat disimpulkan bahwa data residual tersebut berdistribusi normal dikarenakan histogram tersebut tidak miring ke kiri dan membentuk lonceng terbalik.

2. Normal Probability plot

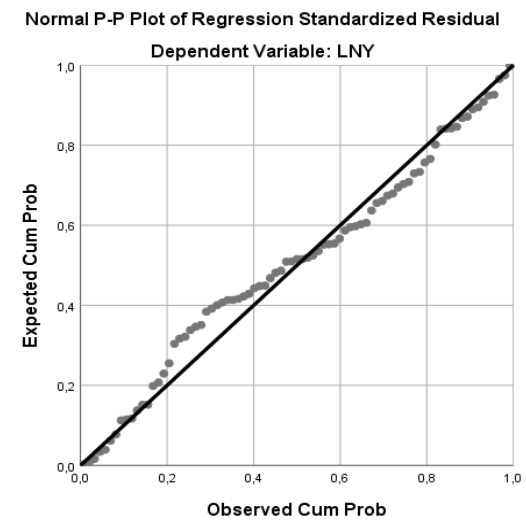

\section{Gambar 3.Garfik Histogram}

Berdasarkan grafik normal probability plot diatas yang telah dilakukan transformasi, menunjukan bahwa titik-titik disekitar garis diagonal dan mengikuti garis diagonal. Jadi dapat disimpulkan bahwa grafik diatas berdistribusi normal.

\section{a. Analisis Statistik}

\section{Tabel 2.}

One-Sample Kolmogorov-Smirnov Test

\begin{tabular}{llr} 
& & \multicolumn{2}{c}{ Unstandardized } \\
& & Residual \\
\hline $\mathrm{N}$ & Mean & 81 \\
\hline Normal Parameters & &, 0000000 \\
\cline { 2 - 3 } & Std. Deviation & 2,50249633 \\
\hline Most Extreme Differences & Absolute &, 098 \\
\cline { 2 - 3 } & Positive &, 059 \\
\cline { 2 - 3 } & Negative &,- 098 \\
\hline Test Statistic & &, 098 \\
\hline Asymp. Sig. (2-tailed) & &, $052^{\mathrm{c}}$ \\
\hline
\end{tabular}

a. Test distribution is Normal.

b. Calculated from data. 


\section{c. Lilliefors Significance Correction.}

Berdasarkan data pada tabel diatas, uji normalitas dengan menggunakan statistik KolmogrovSmirnov, dapat diketahui bahwa nilai Kolmogrov-Smirnov dengan variabel Corporate Risk (X1), Leverage (X2), Sales Growth (X3), dan Tax Avoidance (Y) dengan nilai signifikan 0,052 > 0,05 yang dapat disimpulkan bahwa data tersebut distribusi normal.

\section{Uji Multikolinearitas}

Uji ini bertujuan untuk menguji apakah model regresi ditemukan adanya korelasi antar variabel bebas. Untuk menguji multikolonieritas dapat ditunjukkan dengan menggunakan nilai Tolerance $\leq 0.10$ atau sama dengan nilai $\mathrm{VIF} \geq 10$.

Hasil pengujian multikolinearitas dapat dilihat dari table dibawah ini:

Tabel 3.

\section{Coefficients $^{\mathrm{a}}$}

\begin{tabular}{|c|c|c|c|c|c|c|c|c|}
\hline \multirow{2}{*}{\multicolumn{2}{|c|}{ Model }} & \multicolumn{2}{|c|}{$\begin{array}{l}\text { Unstandardized } \\
\text { Coefficients }\end{array}$} & \multirow{2}{*}{$\begin{array}{l}\text { Standardized } \\
\text { Coefficients } \\
\text { Beta }\end{array}$} & \multirow[b]{2}{*}{$\mathrm{T}$} & \multirow[b]{2}{*}{ Sig. } & \multicolumn{2}{|c|}{$\begin{array}{l}\text { Collinearity } \\
\text { Statistics }\end{array}$} \\
\hline & & B & Std. Error & & & & & VIF \\
\hline 1 & $\begin{array}{l}\text { (Constant } \\
\text { ) }\end{array}$ & 11,643 & 6,962 & & 1,672 & ,099 & & \\
\hline & LNX1 & ,082 & , 100 & ,089 &, 815 & ,418 & ,961 & 1,041 \\
\hline & LNX2 &,- 368 & ,502 &,- 079 &,- 733 & ,466 & ,969 & 1,032 \\
\hline & LNX3 & ,245 & 083 & ,316 & 2,938 & ,004 & ,982 & 1,018 \\
\hline
\end{tabular}

a. Dependent Variable: LNY

Tabel diatas menunjukkan bahwa nilai tolerance variabel Corporate Risk (X1), Leverage (X2), Sales Growth (X3) lebih besar 0,1 (1,018>0,1) maka dapat disumpulkan bahwa tidak terjadi multikoloniearitas. Nilai VIF yang diperoleh untuk variabel Corporate Risk, Leverage, Sales Growth.

\section{Uji Autokorelasi}

Uji ini bertujuan menguji apakah dalam model regresi linear ada korelasi antara kesalahan pengganggu pada periode $t$ dengan kesalahan pengganggu pada periode t-1 (sebelumnya). Untuk menguji apakah ada autokorelasi dapat digunakan Uji Durbin-Watson (DW Test).

\section{Tabel 4.}

\begin{tabular}{|c|c|c|c|c|c|}
\hline \multicolumn{6}{|c|}{ Model Summary $^{b}$} \\
\hline Model & $\mathrm{R}$ & R Square & $\begin{array}{ll}\text { Adjusted } & \mathrm{R} \\
\text { Square } & \end{array}$ & $\begin{array}{l}\text { Std. Error of } \\
\text { the Estimate }\end{array}$ & $\begin{array}{l}\text { Durbin- } \\
\text { Watson }\end{array}$ \\
\hline 1 &, $356^{\mathrm{a}}$ &, 127 & ,093 & 2,55078 & 1,472 \\
\hline
\end{tabular}

a. Predictors: (Constant), LNX3, LNX2, LNX1

b. Dependent Variable: LNY

Tabel diatas menunjukan bahwa nilai DW yang diperoleh sebesar 1.472. Cara pengukuran uji autokorelasi adalah $\mathrm{du}<\mathrm{dw}<4$-dl. Nilai dl dalam penelitian ini menggunakan 3 variabel dan nilai du menggunakan sampel penelitian sebanyak 90 . Nilai $\mathrm{dl}=1,6410$ dan nilai $\mathrm{du}=1.70262$, maka hasil 
pengukuran adalah $1.70262>1.472<(4-1.61190)$ sehingga $1.70262>1.472<2.3881$ sehingga dapat disimpulkan bahwa pengujian tidak meyakinkan atau tidak dapat disimpulkan

\section{Uji Heteroskedastistias}

Uji ini bertujuan untuk menguji apakah dalam model regresi terjadi ketidaksamaan variance dari residual satu pengamatan ke pengamatan yang lain. Untuk menguji ada atau tidaknya heteroskedastisitas dideteksi dengan Uji White. Cara pengambilan keputusan dapat dilihat dari grafik Scatterplot berikut ini :

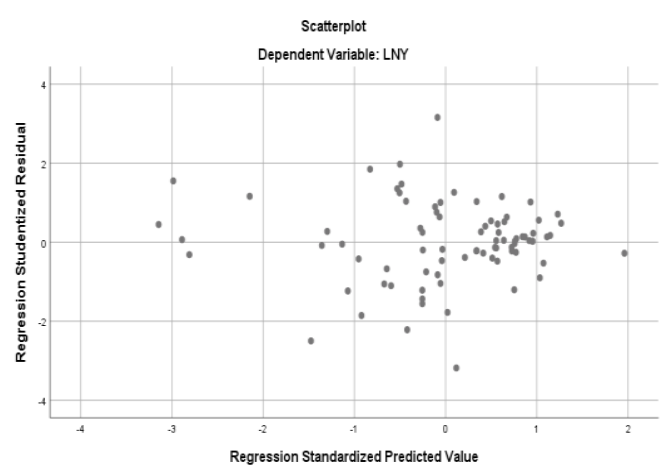

Gambar 4. Scatterplot

Sedangkan untuk uji statistik dapat digunakan uji white pada tabel berikut ini :

Tabel III. 4

\section{Model Summary}

\begin{tabular}{lr|r|r|r} 
Model & R & R Square & \multicolumn{1}{|c}{$\begin{array}{c}\text { Adjusted R } \\
\text { Square }\end{array}$} & $\begin{array}{l}\text { Std. Error of } \\
\text { the Estimate }\end{array}$ \\
\hline 1 &, $440^{\mathrm{a}}$ &, 194 &, 162 & 9,77190 \\
\hline
\end{tabular}

a. Predictors: (Constant), LNX3, LNX2, LNX1

Chi Square $_{\text {hitung hitung } 15.714 \text { sedangkan Chi Square }}$ tabel 5.99146 dengan nilai signifikan 0.05 maka dapat disimpulkan Chi Square hitung $>$ Chi Square $_{\text {tabel }}$ yaitu $15.714>5.99146$ sehingga kesimpulannya adalah ternyata herteroskedastisitas.

\section{Uji Hipotesis secara Simultan ( Uji f)}

Tabel III. 5

\begin{tabular}{|c|c|c|c|c|c|c|}
\hline \multicolumn{7}{|c|}{ ANOVA $^{a}$} \\
\hline Model & & $\begin{array}{l}\text { Sum of } \\
\text { Squares }\end{array}$ & Df & Mean Square & F & Sig. \\
\hline \multirow[t]{3}{*}{1} & Regression & 72,658 & 3 & 24,219 & 3,722 &, $015^{b}$ \\
\hline & Residual & 500,999 & 77 & 6,506 & & \\
\hline & Total & 573,657 & 80 & & & \\
\hline
\end{tabular}

a. Dependent Variable: LNY

b. Predictors: (Constant), LNX3, LNX2, LNX1 
Dari tabel diatas, dapat dilihat bahwa hasil $F_{\text {hitung }}$ sebesar 3.722 dengan nilai signifikan 0,015 , sedangkan $F_{\text {tabel }}$ sebesar 2,.72 dengan nilai signifikan 0,05 maka dapat disimpulkan bahwa $F_{\text {hitung }}>F_{\text {tabel }}$ yaitu $3.722>2.72$ dan signifikan $0,015>0,05$, sehingga keputusannya $\mathrm{H}_{0}$ ditolak dan $\mathrm{H}_{\mathrm{a}}$ diterima yang artinya variabel Corporate Risk, Laverage dan Sales Growthberpengaruh dan tidak signifikan Terhadap Tax AvoidancePerusahaan Pertambanganyang terdaftar di Bursa Efek Indonesia Periode 2015-2017.

\section{Uji Hipotesis secara Parsial ( Uji t)}

Uji t menunjukkan seberapa jauh pengaruh satu variabel penjelas/independen secara individual dalam menerangkan variansi variabel dependen.

\section{Tabel III. 6}

\section{Coefficients $^{\mathrm{a}}$}

\begin{tabular}{|c|c|c|c|c|c|c|}
\hline \multicolumn{2}{|c|}{ Model } & \multicolumn{2}{|c|}{ Unstandardized Coefficients } & $\begin{array}{l}\text { Standardized } \\
\text { Coefficients } \\
\text { Beta }\end{array}$ & $\mathrm{t}$ & Sig. \\
\hline \multirow[t]{4}{*}{1} & (Constant) & 11,643 & 6,962 & & 1,672 & ,099 \\
\hline & LNX1 & ,082 &, 100 & ,089 & ,815 & ,418 \\
\hline & LNX2 &,- 368 & ,502 &,- 079 &,- 733 & ,466 \\
\hline & LNX3 & ,245 & ,083 & ,316 & 2,938 & ,004 \\
\hline
\end{tabular}

a. Dependent Variable: LNY

Hasil pengujian statistic secara parsial sebagai berikut :

1. Tabel diatas menunjukkan variabel Corporate Risk mempunyai $t_{\text {hitung }}$ sebesar 0.815 dengan nilai signifikan 0,418, sedangkan $t_{\text {tabel }}$ sebesar 1.99125 dengan nilai signifikan 0,05 sehingga dapat disimpulkan bahwa $t_{\text {hitung }}<t_{\text {tabel }}$ yaitu $0.815<1.99125$ dan nilai signifikan $0,418>0,05$ yang artinya $\mathrm{H}_{0}$ ditolak dan $\mathrm{H}_{\mathrm{a}}$ diterima yang artinya variabel Corporate Risk berpengaruh dan tidak signifikan TerhadapTax AvoidancePada Perusahaan Pertambangan yang terdaftar di Bursa Efek Indonesia Periode 2015-2017.

2. Tabel diatas menunjukkan variabel Leverage mempunyai $t_{\text {hitung }}$ sebesar -0.733 dengan nilai signifikan 0,466, sedangkan $t_{\text {tabel }}$ sebesar 1.99125 dengan nilai signifikan 0,05 sehingga dapat disimpulkan bahwa $t_{\text {hitung }}<\mathrm{t}_{\text {tabel }}$ yaitu $-0.733<1.99125$ dan nilai signifikan 0,466 $>0,05$ yang artinya $\mathrm{H}_{0}$ ditolak dan $\mathrm{H}_{\mathrm{a}}$ diterima yang artinya variabel Laverage berpengaruh negatif dan tidak signifikan Terhadap Tax AvoidancePada Perusahaan Pertambangan yang terdaftar di Bursa Efek Indonesia Periode 2015-2017.

3. Tabel diatas menunjukkan variabel Sales Growthmempunyai $t_{\text {hitung }}$ sebesar 2.938 dengan nilai signifikan 0,004, sedangkan $t_{\text {tabel }}$ sebesar 1.99125 dengan nilai signifikan 0,05 sehingga dapat disimpulkan bahwa $t_{\text {hitung }}>\mathrm{t}_{\text {tabel }}$ yaitu $2.938>1.99125$ dan nilai signifikan $0,004<0,05$ yang artinya $\mathrm{H}_{0}$ ditolak dan $\mathrm{H}_{\mathrm{a}}$ diterima yang artinya variabel Sales Growthberpengaruh dan tidak signifikan Terhadap Tax AvoidancePada Perusahaan Pertambangan yang terdaftar di Bursa Efek Indonesia Periode 2015-2017. 


\section{Uji Linier Sederhana}

a. Corporate risk terhadap tax avoidance

\section{Coefficients $^{\mathrm{a}}$}

\begin{tabular}{|c|c|c|c|c|c|c|}
\hline \multirow{2}{*}{\multicolumn{2}{|c|}{ Model }} & \multicolumn{2}{|c|}{ Unstandardized Coefficients } & \multirow{2}{*}{$\begin{array}{c}\text { Standardized } \\
\text { Coefficients } \\
\text { Beta }\end{array}$} & \multirow[b]{2}{*}{$\mathrm{t}$} & \multirow[b]{2}{*}{ Sig. } \\
\hline & & $\mathrm{B}$ & Std. Error & & & \\
\hline \multirow[t]{2}{*}{1} & (Constant) & 9,436 & 1,260 & & 7,488 &, 000 \\
\hline & LNX1 &, 129 & 103 & 140 & 1,256 & ,213 \\
\hline
\end{tabular}

a. Dependent Variable: LNY

Berdasarkan tabel diatas diketahui $\mathrm{t}_{\text {hitung }}$ sebesar 1,256 < $\mathrm{t}_{\text {tabel }} 1.66347$ sehingga dapat disimpulkan bahwasannya corporate Risk(X)tidak berpengaruh terdapat Tax Avoidance(Y).

b. Leverage terhadap tax avoidance

\section{Coefficients $^{\mathrm{a}}$}

\begin{tabular}{|c|c|c|c|c|c|c|}
\hline \multirow{2}{*}{\multicolumn{2}{|c|}{ Model }} & \multicolumn{2}{|c|}{ Unstandardized Coefficients } & \multirow{2}{*}{$\begin{array}{c}\text { Standardized } \\
\text { Coefficients } \\
\text { Beta }\end{array}$} & \multirow[b]{2}{*}{$\mathrm{t}$} & \multirow[b]{2}{*}{ Sig. } \\
\hline & & $\mathrm{B}$ & Std. Error & & & \\
\hline \multirow[t]{2}{*}{1} & (Constant) & 14,133 & 5,789 & & 2,441 & ,017 \\
\hline & LNX2 &,- 246 & ,440 &,- 059 &,- 558 & ,578 \\
\hline
\end{tabular}

a. Dependent Variable: LNY

Berdasarkan tabel diatas diketahui $t_{\text {hitung }}$ sebesar $-0,558<\mathrm{t}_{\text {tabel }} 1.66216$ sehingga dapat disimpulkan bahwasannya leverage $(\mathrm{X})$ tidak berpengaruh terdapat Tax Avoidance $(\mathrm{Y})$.

c. Sales Growth terhadap tax avoidance

\begin{tabular}{|c|c|c|c|c|c|c|}
\hline \multicolumn{7}{|c|}{ Coefficients $^{\mathbf{a}}$} \\
\hline \multirow{3}{*}{\multicolumn{2}{|c|}{ Model }} & \multirow{2}{*}{\multicolumn{2}{|c|}{ Unstandardized Coefficients }} & Standardized & & \\
\hline & & & & Coefficients & & \\
\hline & & B & Std. Error & Beta & $\mathrm{t}$ & Sig. \\
\hline \multirow[t]{2}{*}{1} & (Constant) & 7,672 & ,945 & & 8,120 & ,000 \\
\hline & LNX3 & ,259 & ,073 &, 353 & 3,564 &, 001 \\
\hline
\end{tabular}

a. Dependent Variable: LNY

Berdasarkan tabel diatas diketahui $t_{\text {hitung }}$ sebesar 3.564> $t_{\text {tabel }} 1.66216$ sehingga dapat disimpulkan bahwasannya sales growth $(\mathrm{X})$ berpengaruh terdapat Tax Avoidance $(\mathrm{Y})$.

\section{KESIMPULAN}

Penelitian ini menyatakan bahwa Corporate Risk tidak berpengaruh dan tidak signifikan terhadap Tax Avoidance pada perusahaan pertambangan yang terdaftar di Bei periode 2015-2017. Dan menurut penelitian Aristianto Dwi Saputra(2018) menyatakan bahwaCorporate risk tidak berpengaruh terhadap tax avoidance. Penelitian (Paglivora 2010) menjelaskan bahwa indikator penghitungan dapat menunjukan karakter eksekutif dalam sebuah perusahaan apakah risk taker atau risk averse. Besar kemungkinan karakter eksekutif dalam penelitian iniadalah risk averse dimana karakter ini cenderung tidak berani mengambil risiko yang tinggi. Sehingga dalam pengelolaan perusahaan yang minim terhadap risiko tidak memiliki dampak terhadap penghindaran pajak, sehingga corporate risk tidak berpengaruh terhadap 
penghindaran pajak. Hasil ini juga didukung oleh penelitian (Butje 2014) yang menjelaskan bahwa corporaterisk tidak berpengaruh terhadap tax avoidance. Akan tetapi hasil penelitian ini bertentangan dengan penelitian yang dilakukan oleh (Dewi dan Jati 2014) yang menyebutkan bahwa corporate risk berpengaruh negatif terhadap tax avoidance.

Hasil penelitian ini menyatakan bahwa Leveragetidak berpengaruhdan tidak signifikan Terhadap Tax Avoidancepada perusahaan pertambangan yang terdaftar di Bursa Efek Indonesia Periode 2015-2017. Demikian pula hasil penelitian didukung oleh Khoirunnisa Alviyani(2016) juga menyatakan bahwa Laverage tidak berpengaruh pada penghindaran pajak. Dan Surbakti (2012) menyatakan bahwa leverage tidak berpengaruh signifikan terhadap penghindaran pajakyang dilakukan diperusahaan dikarenakan sebagian perusahaan mengunakan pinjaman modal kepada pemegang saham atau investor sehingga beban yang ditimbulkan tidak dapat dikurangi dengan laba kena pajak.

Penelitian ini menyatakan bahwa Sales Growthberpengaruh dan tidak signifikan Terhadap Tax AvoidancePada Perusahaan Pertambangan yang terdaftar di Bursa Efek Indonesia Periode 2015-2017. Berdasarkan hasil penelitian Budiman dan Sutiyono (2012) menjelaskan bahwa Sales Growth berpengaruh signifikan terhadap Cash Effetive Tax Ratio(CETR) yang merupakan indikator dari terjadinya aktifitas penghindaran pajak yang terjadi pada perusahaan manufaktur yang terdaftar di BEI tahun 2006-2010. Menurut Deitiani (2011) pertumbuhan penjualan perusahaan dapat memprediksi seberapa besar profit yang akan diperoleh dengan besarnya pertumbuhan penjualan. Semakin besar volume penjualan suatu perusahaan menunjukan bahwa pertumbuhan penjualan perusahaan tersebut semakin meningkat. Pendapatanini didukung dari hasil penelitian yang dilakukan oleh Dewinta dan Setiawan (2016), dimana penelitian tersebut menunjukan hasil bahwa sales growth berpengaruh positif terhadap penghindaran pajak.

\section{DAFTAR PUSTAKA}

Aristianto, Dwi Saputra . 2018. Pengaruh Insentif Eksekutif, Corporate Risk, Corporate Governance dan Konservatisme Akuntansi terhadap Tax avoidance

Budiman, Judi dan Setiyono. 2012. Pengaruh Karakter Eksekutif Terhadap Penghindaran Pajak (TaxAvoidance). Electronic Theses \& Dissertations (ETD) Univeritas Gajah Mada.

Butje, Stella. 2014. "Pengaruh Karakter Eksekutif dan Koneksi Politik Terhadap Tax avoidance" 4 (2): 1 9.

Darmawan, I. G., \& Sukartha, I. M. (2014). Pengaruh Penerapan Corporate Governance,Leverage, Return On Assets dan Ukuran Perusahaan pada Penghindaran Pajak. E-Jurnal Akuntansi Universitas Udayana, 143-161.

Deitiana, T. (2011). Pengaruh Rasio Keuangan, Pertumbuhan Penjualan dan Deviden terhadap Harga Saham13 (1): Jurnal Bisnis dan Akuntansi.

Dewi, Gusti Ayu Pradnyanita, and Maria M Ratna Sari. 2015. "Pengaruh Insentif Eksekutif, Corporate Risk Dan Corporate Governance Pada Tax avoidance.” Jurnal Akuntansi, no. Universitas Udayana: 50-67.

Dewi, Ni Nyoman, and I ketut Jati. 2014. "Pengaruh Karakter Eksekutif, Karakteristik Perusahaan, Dan Dimensi Tata Kelola Perusahaan Yang Baik Pada Tax avoidance Di Bursa Efek Indonesia.” Pengaruh Karakter Eksekutif, Karakteristik Perusahaan, Dan Dimensi Tata Kelola Perusahaan Yang Baik Pada Tax avoidance Di Bursa Efek Indonesia 6 (T): 249-60. 
Khoirunnisa Alviyani. 2016. Pengaruh Corporate Governance, Karakter Ekaekutif, Ukuran Perusahaan, dan Leverage Terhadap Ppenghindaran Pajak (Tax Avoidance)

Low, Angie. 2006. Managerial Risk-Taking Behavior and Equity-Based Compensation. Fisher College of Working Paper, 03-00

Paligorova, Teodora. 2010. Corporate Risk Taking and Ownership Structure, Bank of Canada Working Paper, 2010-3.

Santoso, Iman dan Ning Rahayu. 2013. Corporate Tax Management. Jakarta : Observation \& Research of Taxation (Ortax).

Sugiyono. 2016. Metode Penelitian Bisnis. Jakarta : Penerbit CV Alfabeta.

Surbakti, Theresa Adelina Victoria.2012. Pengaruh Karakteristik Perusahaan dan Reformasi Perpajakan Terhadap Penghindaran Pajak di Perusahaan Industri Manufaktur yang Terdaftar di Bursa Efek Indonesia Tahun 2008-2010.

Swingly.Calvin dan I Made Sukartha. 2015. Pengaruh Karakter Eksekutif, Komite Audit, Ukuran Perusahaan, Leverage, dan Sales Growth pada Tax Avoidance. E-Jurnal Akuntansi Universitas Udayana 10.1 (2015) 